\title{
Cardiac Cell Specification by Defined Factors
}

\author{
Yuika Morita and Jun Takeuchi
}

Our previous study has shown that Tbx5-Gata4-Baf60c-induced functional cardiomyocytes via the ectopic expression of $N k x 2-5 /$ Islet 1 in the mesodermal cells, but not in the endodermal/ectodermal cells [1,2] (Fig. 57.1). Mesp1 is one of the major transcriptional regulators specifying the mesodermal lineage, but it also induces skeletal muscle, hematopoietic and vascular cells as well as cardiac cells [3-5]. Eomesodermin (Eomes), an upstream player of Mesp1, regulates mesodermal cell lineages, but it does not have a potential for specification of cardiac cell fate from cardiovascular lineages either [6]. Therefore, the study of cardiac cell fate specification from the embryonic stem cells by the defined factors still remains at least two major questions.

1. How the cardiac lineage is committed from the mesoderm via repressing skeletal muscle, hematopoietic and vascular cell fates?

2. Are there any factors specifying the cardiac lineage directly from the undifferentiated stem cells?

Y. Morita

MRI, Tokyo Medical and Dental University, Tokyo, Japan

Department of Cardiology, Keio University, Tokyo, Japan

J. Takeuchi $(\square)$

MRI, Tokyo Medical and Dental University, Tokyo, Japan 


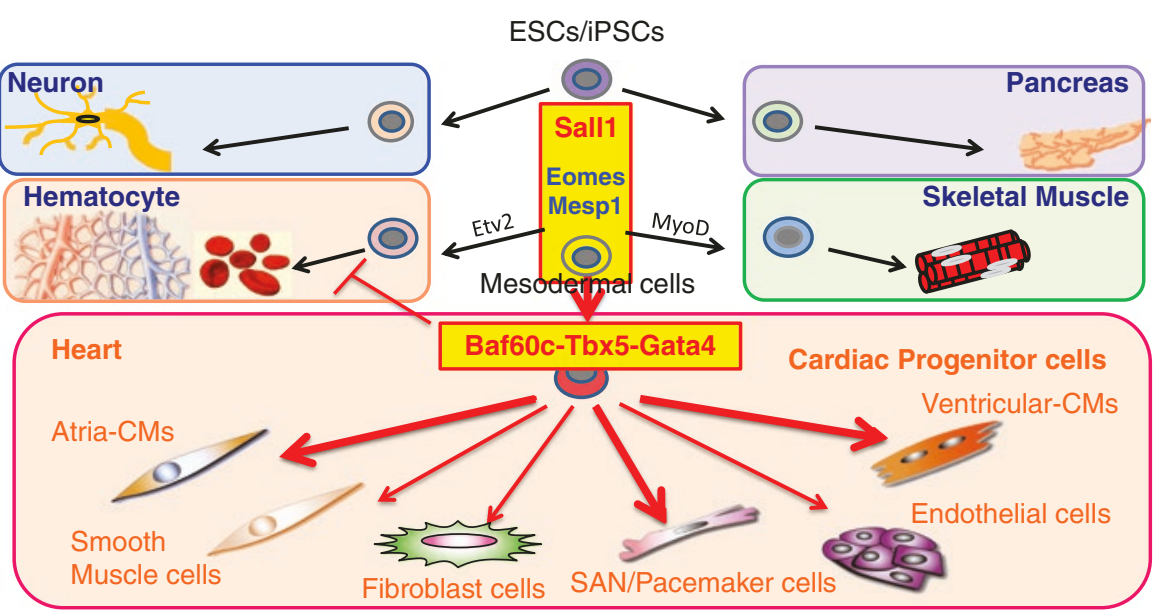

Fig. $\mathbf{5 7 . 1}$ The defined factors for cardiogenesis

To disclose these questions, we performed RNA sequencing from the anterior field at the early cardiac crescent stage, and we identified Sall1 gene as a suitable key regulator for the cardiac cell lineage [7]. Overexpression of Sall1 in mouse ES accelerated cardiogenesis and also promoted cardiac cell fate in human iPS cells with upregulation of several cardiac transcriptional genes (ISLET1/NKX2-5/ $M E F 2 C$ ) and sarcomeric genes (TNNT2/MYL7/MYH6/MYH7). Sall1 also acts as a modulator to recruit the histone-modification/the chromatin remodeling factors and the other transcriptional factors to commit the cardiac cell fate. Interestingly, permanent expression of Sall1 in differentiating human iPS cells increased the number of cardiac progenitor cells [7] (Fig. 57.2). These data suggest that Sall1 acts as a key factor to promote and maintain the cardiac progenitor cell phase from undifferentiating stem cells, and down-regulation of Sall1 expression after induction of cardiac progenitor cells is necessary to shift the cell fate to cardiomyocyte differentiation.

Our data just show that a novel gene, Sall1, programs cardiac cell fate and accelerates cardiogenesis, but this factor may act as a defined player for the cardiac cell fate with and the other transcriptional factors to define. Thus, the study for isolation of in vivo Sall1 partners and establishment of its regulation will give us the next window for the program/reprogram research (Fig. 57.1). 

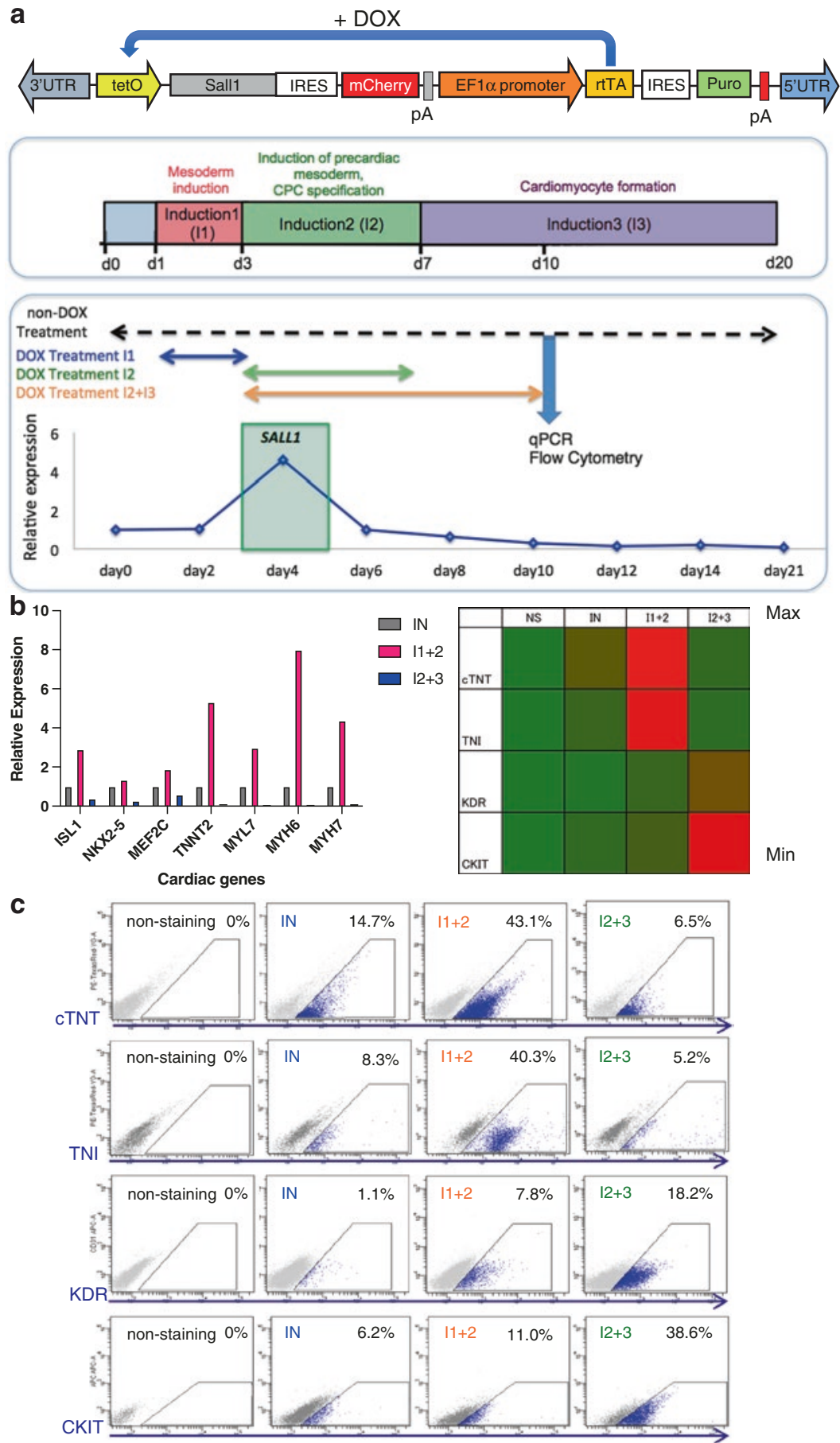

Fig. 57.2 The critical expression of Sall1 for promoting cardiogenesis 


\section{References}

1. Takeuchi JK, Bruneau BG. Direct transdifferentiation of mouse mesoderm to heart tissue by defined factors. Nature. 2009;459:708-11.

2. van Weerd JH, Koshiba-Takeuchi K, Kwon C, Takeuchi JK. Epigenetic factors and cardiac development. Cardiovasc Res. 2011;91:203-11.

3. Bondue A, Lapouge G, Paulissen C, Semeraro C, Iacovino M, Kyba M, Blanpain C. Mesp1 acts as a master regulator of multipotent cardiovascular progenitor specification. Cell Stem Cell. 2008;3:69-84.

4. Chan S, Shi X, Toyama A, Arpke RW, Dandapat A, Iacovino M, Kang J, Le G, Hagen HR, Garry DJ, Kyba M. Mesp1 patterns mesoderm into cardiac, hematopoietic, or skeletal myogenic progenitors in a context-dependent manner. Cell Stem Cell. 2013;12:587-601.

5. Lescroat F, Wang X, Lin X, Swedlund B, Gargouri S, Sanchez-Danes A, Moignard V, Dubois C, Paulissen C, Kinston S, Gottgens B, Blanpain C. Defining the earliest step of cardiovascular lineage segregation by single-cell RNA-seq. Science. 2018;359(6380):1177-81.

6. Van den Ameele J, Tiberi L, Bondue A, Paulissen C, Herpoel A, Lacovino M, Kyba M, Blanpain $\mathrm{C}$, Vanderhaeghen P. Eomesodermin inducesMesp1 expression and cardiac differentiation from embryonic stem cells in the absence of Activin. EMBO Rep. 2012;13(4):355-62.

7. Morita Y, Andersen P, Hotta A, Tsukahara Y, Sasagawa N, Hayashida N, Koga C, Nishikawa M, Saga Y, Evans SM, Koshiba-Takeuchi K, Nishinakamura R, Yoshida Y, Kwon C, Takeuchi JK. Sall1 transiently marks undifferentiated heart precursors and regulates their fate. J Mol Cell Cardiol. 2016;92:158-62.

Open Access This chapter is licensed under the terms of the Creative Commons Attribution 4.0 International License (http://creativecommons.org/licenses/by/4.0/), which permits use, sharing, adaptation, distribution and reproduction in any medium or format, as long as you give appropriate credit to the original author(s) and the source, provide a link to the Creative Commons license and indicate if changes were made.

The images or other third party material in this chapter are included in the chapter's Creative Commons license, unless indicated otherwise in a credit line to the material. If material is not included in the chapter's Creative Commons license and your intended use is not permitted by statutory regulation or exceeds the permitted use, you will need to obtain permission directly from the copyright holder.

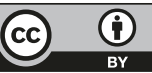

